\title{
Accidents at Work from Exposure to Biological Material Contamination of Viral Hepatitis "B" and "C" in a Brazilian Capital*
}

\author{
Hanna Beatriz Bacelar Tibães1, Isabela Mie Takeshita², Adelaide De Mattia Rocha ${ }^{1,3}$ \\ ${ }^{1}$ Federal University of Minas Gerais (UFMG), Belo Horizonte, Brazil \\ ${ }^{2}$ College of Nursing, Federal University of Minas Gerais (UFMG), Belo Horizonte, Brazil \\ ${ }^{3}$ College of Nursing, University of São Paulo, São Paulo, Brazil \\ Email: hannabacelar@gmail.com, isa jx@yahoo.com.br, Adelaide@enf.ufmg.br
}

Received 26 March 2014; revised 27 April 2014; accepted 11 May 2014

Copyright @ 2014 by authors and Scientific Research Publishing Inc.

This work is licensed under the Creative Commons Attribution International License (CC BY). http://creativecommons.org/licenses/by/4.0/

(c) $\underset{\mathrm{EY}}{0}$ Open Access

\section{Abstract}

Background: Occupational exposure to biological materials is a serious risk to the health of workers in their workplaces, due to the possibility of transmitting pathogens such as Hepatitis B Virus (HBV), Hepatitis C Virus (HCV), and Human Immunodeficiency Virus (HIV). The aim of this study was to analyze the accidents of exposure to biological material which resulted in contamination of Hepatitis $B$ and $C$ in the municipal health Belo Horizonte. Methods: Epidemiological study with cross-sectional design performed by querying the data on accidents at work involving exposure to biological materials and notification data of Viral Hepatitis in the Information System for Notifiable Diseases (SINAN) for the period of 2007 to June 2011, filed with the municipal government of Belo Horizonte. A descriptive analysis was performed using frequency distribution and percentages. Results: The 45 research records were arranged in professional categories, with $57.77 \%$ of incidents being ignored, followed by $24.44 \%$ nursing technicians, $6.66 \%$ nursing assistants, and $2.22 \%$ marketers, housekeeping, administrators, janitors, and builders. The average age was 39 years and $64.44 \%$ of the professionals were female. At the notification of the accident, $75.55 \%$ of professionals were not registered at CAT, and $92.85 \%$ of exposures occurred in the hospital; 64.29\% in contact with blood; $35.71 \%$ of the causative agent was without needle lumen, $28.57 \%$ during administration of intravenous medication, and $57.14 \%$ from percutaneous exposure. In the distribution of occupation, $57.78 \%$ were contaminated with viral Hepatitis $B$ and $C$. With vaccination regimens for Hepatitis $B, 66.67 \%$ of the cases went to nursing assistants and $42.22 \%$ were "ignored". Conclusion: These data confirm the need for reorientation of working practices during daily activities of health workers and guidance for notification of occupational accidents involving biological material and viral Hepatitis $B$ and $C$ in order to improve the quality of the records.

\footnotetext{
*This manuscript is the result of the dissertation entitled "Analysis of the data relating to accidents due to exposure to biological material contamination of Viral Hepatitis B and C in a Brazilian capital” in the School of Nursing, Federal University of Minas Gerais, 2012.

How to cite this paper: Tibães, H.B.B., Takeshita, I.M. and Rocha, A.DeM. (2014) Accidents at Work from Exposure to Biological Material Contamination of Viral Hepatitis " $\mathrm{B}$ " and " $\mathrm{C}$ " in a Brazilian Capital. Occupational Diseases and Environmental Medicine, 2, 39-47. http://dx.doi.org/10.4236/odem.2014.22005
} 


\section{Keywords}

\section{Work Accidents, Hepatitis B, Hepatitis C, Health of the Worker, Exposure to Biological Agents}

\section{Introduction}

The industrial accident takes on a leading role in illness among workers, to be associated with dysfunction of varying severity, from small lesions with a quick remedy to serious accidents that cause temporary or permanent disability, and which may lead to the death of the worker [1] [2]. In this sense, occupational exposure to biological materials is a serious risk to the health of workers in their workplaces, due to the possibility of transmitting pathogens such as Hepatitis B Virus (HBV) and Hepatitis C Virus (HCV).

Viral Hepatitis diseases are caused by different etiological agents, universal distribution, which have in common the hepatotropism. The causative virus of hepatitis determines a wide variety of clinical presentations, from asymptomatic carrier of acute or chronic hepatitis, cirrhosis, and even hepatocellular carcinoma (HCC). Hepatitis B is considered as one of the most common and serious infectious diseases due to the high morbidity and mortality [3]. HBV transmission can occur via parenteral (transfusion, before the institution of screening in blood banks, sharing of needles, syringes or other equipment containing infected blood, medical/dental procedures with contaminated blood without proper sterilization of instruments, performance of tattoos without implementation of biosafety regulations, conveying contaminated blood), sexual (in unprotected sex), vertical (especially during childbirth), and continuity solution (skin and mucous membranes), since the Hepatitis C Virus (HCV) is only transmitted efficiently through the blood [4].

Acute Hepatitis C is usually asymptomatic, but it is estimated that $25 \%$ of cases may present with elevated transaminase levels up to 15 times of the normal limit [5]. According to [6], about eighty-five percent of cases progress to a chronic form, with viremia and elevated transaminases, mostly asymptomatic and without signs of liver disease

It is estimated that under the risk of contracting Hepatitis B (HBV), the general population is 5\%, while for the health workers, the seroprevalence of HBV is 2 to 4 times higher, and the annual incidence is $5 \%$ to 10 times higher than that in the general population. Most infected individuals concentrated in certain geographic areas, such as Southeast Asia and Central Africa. In Brazil, three patterns of endemicity were recognized, and this was attributed to the socio-economic and cultural characteristics of different regions of the country differences. The pattern of high endemicity is present in the Amazon, some places of the Espirito Santo and west of Santa Catarina; intermediate endemicity occurs in the Northeast and Midwest, and low endemicity in the regions South and Southeast [7].

Exposure to biological material is linked to the possibility of contact in the workplace with blood and other body fluids, such as naso-pharyngeal secretions which secrete from skin lesions, cerebrospinal fluid, and mucosal splash which may be contaminated with various pathogens [8]. In this type of accident, professionals often experience feelings of frustration, fear of being slighted or excluded by colleagues and family, and fear of seroconversion [1].

According to the CDC [9], the risk of contamination by biological material in the presence of etiological agents for $\mathrm{HBV}$ is $6 \%$ to $30 \%$, and $\mathrm{HCV}$ is from $0.5 \%$ to $2 \%$ respectively. This risk is proportional to the handling of sharp materials and fluids, with an average of $1.8 \% \mathrm{HCV}$ infection following percutaneous occupational exposure, and can vary from $1 \%$ to $10 \%$. In the case of HBV in patients with HBsAg positive, the estimated risk is presented between $6 \%$ and $30 \%$, and may reach $40 \%$ when no prophylactic measure is adopted. The risk of acquiring HBV after percutaneous exposure can reach up to $62 \%$ of viral load in patients with HBeAg positive serology, which reflects a high rate of viral replication and a greater amount of circulating virus [10].

The Hepatitis B Virus can remain stable on environmental surfaces, even maintaining its power of infectivity for up to seven days [8]. It is estimated that approximately 400 million individuals are infected with HBV in the world population [11]. And of these, 2 million have serologic evidence of Hepatitis B and about 170 million are chronically infected with HCV, with 3 to 4 million new infections occurring each year [12].

It is estimated that the occurrence of accidents due to exposure to biological material can affect more than 3 million professionals in the health area, which increases the number of individuals infected with hepatitis each 
year by percutaneous occupational exposure [13].

The monitoring and control of workplace accidents by exposure to biological material and contamination by Hepatitis-Hepatitis B and C, in the city of Belo Horizonte, are held by the Notifiable Diseases Information System (SINAN), through the "Record of Inquiry Work Accident with Exposure to Biological Material", and the Sheet Investigation Viral Hepatitis. The System for Notifiable Diseases (SINAN) was created by the Ministry of Health and deployed as SINAN WINDOWS from 1993 throughout the national network. However, the implantation was performed heterogeneously at the states and municipalities [14]. In Belo Horizonte the system was deployed in 2001, and remained until 2006, being overhauled by the Ministry of Health to SINAN NET aiming to innovate the system and improve the quality of information from reporting on national television.

In 2007 and 2008, The Notification System of Reportable Diseases (SINAN) recorded nearly 13,749 accidents with biological material in 1,449,307 healthcare professionals in Brazil [15]. Although the risk of transmission of infectious diseases by accidents involving exposure to biological material for the professionals who work in health care is established, it is understood that the number of infections from these events is still unknown. This fact is due to the scarcity of standardized surveillance data and underreporting which does not allow for interpretation of the magnitude of the problem. Considering that most HBV carriers are asymptomatic or oligosymptomatic, underreporting happens in The Notification System of Notifiable Diseases (SINAN) [16]. Regarding this issue, this study proposed to analyze the accidents of exposure to biological material which [17] resulted in contamination of Hepatitis B and C in the municipal health district of Belo Horizonte, and to verify factors associated with accidents at work by exposure to biological material and consequent contamination of Viral Hepatitis B and C.

\section{Methods}

Cross-sectional epidemiological study on occupational accidents with exposure to biological material and contamination by Hepatitis B and C occurred in the city of Belo Horizonte, in the period of 2007 to June 2011. The choice for the period 2007 to 2011 to collect data in SINAN is justified considering that the last update of the program on national television. Along with this the city of Belo Horizonte front of the State Department of Health of Minas Gerais (SES-MG), from the Resolution no. 1481 on May 16, 2008 added to the entire state of Minas Gerais, state grievances to the National List diseases of Compulsory Notification among them accidents involving exposure to biological material and the Viral Hepatitis with objectives to improve the notification throughout the state of Minas Gerais [16]. This study was developed in the Information System of the City Health Department of Belo Horizonte in the databases of the Information System for Notifiable DiseasesSINAN/PBH. The choice of the Notifiable Diseases Information System (SINAN)—-Data Accident Investigation Working with Exposure to Biological Material" refers to its specificity and also permits behavioral and causal factors of the accident by biological material and of Viral Hepatitis. The choice of "Data for Research on Viral Hepatitis" also refers to specificity, which allows us to interpret the data reported by Viral Hepatitis B and $\mathrm{C}$ and contracted for work accidents by exposure to biological material upon this record has the variable "having accident suffered by exposure to biological material”.

Data were collected in the database of SINAN referring to data on accidents at work involving exposure to biological material and data of reported contamination of Viral Hepatitis, according to the SINAN investigation files. For criterion of inclusion of the data in the study, we considered the database of Injury with Exposure to Biological Material considered filling the variable, "evolution of the case and specification of the virus", and Hepatitis "B" or Hepatitis "C". As for the database Hepatitis we considered that variables "have suffered work injuries by exposing the biological material", and have "confirmed etiology for Viral Hepatitis 'B' and 'C'”.

For the organization of data collection, we created a secondary database in Excel for Windows after the survey in the SINAN database, towards accomplishing successive approximations of the object under study and assessment of data reliability.

Analyzing the database "Accident with Exposure to Biological Material”, we identified 2101 reported cases, including 14 cases of accidents found with contamination of Viral Hepatitis B and C. In the database entitled "Viral Hepatitis", 3341 cases of Viral Hepatitis Type A, B, C, D, E and associated were identified. Of these, 2781 were proven cases of Viral Hepatitis, but for the sample, only cases that showed contamination of type B, Viral Hepatitis C, and those acquired by accidents involving exposure to biological material were selected, totaling 31 cases. 
The characteristics of accidents recorded by means of the following variables were obtained: age, sex, occupation, notification via CAT, etiological classification for Viral Hepatitis, Hepatitis B vaccination status, time of exposure to biological material developments in the case, the workplace, type of exposure and biological material involved, and circumstances of the accident.

The information was recorded (considering double entry, validation and checking the consistency of information) and coded in a spreadsheet, in the form of an Excel database for Windows, transferred and analyzed by Statistic software version 7 . The final sample consisted of 45 reported cases of accidents at work involving exposure to biological material, which resulted in contamination of Viral Hepatitis B and C.

We conducted a descriptive analysis of the collected data, tabulated and presented with frequency distributions and percentages in tables categorized into socio-demographic aspects; biosafety and characterization of accidents according to occupation, gender, age, notification CAT, vaccination status for Hepatitis B, Viral Hepatitis for etiologic classification, evolution of the case, agent, biological material involved, type of exposure and circumstances of the accident.

The category "ignored" in the data analysis appears frequently, but lets be clear that it is a separate category from reporting SINAN NET, indicating the failure of the employee to respond to the variable.

This study was approved by the Ethics Committee in Research of the Federal University of Minas GeraisCOEP and Municipal Health Department of Belo Horizonte in the document 0449.0.203.410-11P1.

\section{Results}

Records of accidents with biological material that resulted in infection by Viral Hepatitis B and C in SINAN NET totaled 45, distributed in the following professional categories: janitor, nursing assistant, nursing technician, mason/builder, wholesaler, administrator, maid, and category ignored. The higher prevalence of accidents involving biological material according to professional category was in the category ignored, with 26 cases (57.77\%), followed by nursing technicians with 11 (24.44\%), nursing assistants with 03 (6.66\%), then maid, marketer, administrator, janitor and mason combined for just 01 (2.22\%).

In the present study, the 45 workers affected by workplace accidents of biological accidents, 16 cases (35.56\%) belonged to males and 29 (64.44\%) were females. In the categories of janitor, nursing assistant, nursing technician and hotel maid, female gender, with $33.33 \%$. In the categories of mason, merchant and administrator, exclusively male, 03 cases were found (6.66\%). In the ignored category, female gender, $31.11 \%$ compared to $26.67 \%$ male. The average age of the professionals included in this study 39 years with $24.4 \%$ in the under 30 age group, which indicates a relatively young group with plenty of time for work to be completed.

Of the 45 professional victims of accidents involving exposure to biological material and contaminated by Viral Hepatitis, 11 (24.44\%) claim to have completed the Communication Accident of the Work-CAT and 34 (75.55\%) did not communicate the work accident via CAT.

In the study, the occupation distribution and Viral Hepatitis B and Hepatitis C had higher prevalence in the category "ignored", with 26 cases (57.78\%), presenting a serious reality and ignorance in the professional category. The category of nursing technicians showed 11 cases (24.44\%) and nursing assistants 03 (6.67\%). It is noteworthy that Hepatitis B showed more cases than Hepatitis C.

In characterizing exposure and outcome for Hepatitis B and C, exposure to biological material most often occurred for more for more than six months in 27 (60.0\%) cases. Of these, 26 (57.78\%) progressed to chronic Hepatitis and 01 (2.22\%) for acute Hepatitis. The contact with biological material in category "yes", did not define the time of exposure, with 14 (31.11\%) cases, and exposure in the category "less than six month" included 04 $(8.89 \%)$ cases. In clinical forms, it highlighted chronic Hepatitis in 30 (66.67\%) cases, followed by unspecified Hepatitis with 14 (31.11\%) cases.

With regards to vaccination status for Hepatitis B, of the 45 workers participating in the research, the highest frequency was the "unknown" category with 19 (42.22\%) cases. Occupations of nursing assistants and technicians were responsible for $66.67 \%$ and $45.45 \%$ respectively in these cases. Then the vaccination status in the category "not vaccinated" with 12 (26.67\%) cases, and the masons and trader with 01 (2.22\%) and 10 (22.22\%) cases in the category "ignored". In the fully vaccinated, there were $10(22.22 \%)$ cases, with prevalence in the category of nursing technicians with 06 (13.33\%) occurrences, then the category "unknown" with 02 (4.44\%) cases and occupations nursing assistant 01 (2.22\%) and janitor 01 (2.22\%). Incomplete vaccination status registered $04(8.89 \%)$ cases, of which 03 (6.67\%) belonged to the "ignored" and 01 (2.22\%) to occupation adminis- 
trator category.

Regarding the location of the workplace accidents, the hospital had the highest occupational exposures to biological fluids (92.85\%) with 01 case $(7.14 \%)$ occurring outside the hospital. With regards to the causative agents of sharp materials which were involved in most of the accidents, categorized as: needle with lumen, needle without lumen, intracath blade/lancet and others.

Of the total of 14 accidents by exposure to biological material occurring with workers according to the causative agent, 05 (35.71\%) were with the agent without needle lumen, 04 (28.57\%) with needle lumen, 02 (14.28\%) for blade/lancet and other, and 01 with intracath (7.14\%). With regards to the circumstances of the accident, 04 (28.57\%) involved the administration of intravenous medications, 03 (21.42\%) subcutaneous administration of medication, and 02 (14.29\%) related to improper disposal of sharp objects for venous/arterial puncture for blood collection in the trash bags.

In research, database work accidents with exposure to biological material $(n=14)$ found that the most frequent organic material was blood with 09 cases (64.29\%), followed by pleural fluid and the ignored category, each with 02 (14.29\%), and only 01 (7.14\%) with blood fluid. Regarding exposure of the accident, 08 (57.14\%) were affected with percutaneous injuries, 02 (14.29\%) ignored the exposure, and 01 (7.14\%) for fluid with blood, percutaneous/other unspecified exposure to the whole skin.

\section{Discussion}

The predominant professional category was ignored, a fact that points to a major flaw in the notification of occupational accidents process, making it difficult to associate the profession of the employee and the accident victims to the risk situations of their work and establishment of the causal link with the accident. It is known that the nursing staff consists of registered nurses, practical nurses and nursing aides, and that there is a predominance of the quantitative nursing technicians, as shown by the number of members of (Federal and Regional) Boards of Nursing and the Brazilian Nursing Association. This may explain the prevalence of workplace accidents involving biological material in this profession.

The average age of the professionals corroborate consistent results were found in the literature, suggesting a higher incidence of accidents with biological material among young adult women nursing professionals, which reflects the composition of the category of technicians and nursing assistants, to be traditionally and historically female [18]-[20] [21].

Despite the importance of the completion and issuance of CAT, underreporting due to non-fulfillment after the accident with biological material is present. Most of the time, the CAT is ignored and/or not completed or issued by the workers. Underreporting reflects the low perceived risk for the transmission of pathogens, including the percutaneous exposures involving blood, which are considered high risk accidents. Other studies suggest reasons for the underreporting of accidents as the lack of importance given to accidents and methods of exposure, the unknown risk of infection, the carelessness, lack of time, not finding it necessary to make the notification, fear and/or rejection by the team, in addition to professional embarrassment. This is also highlighted by the difficulty of the worker to have access to the occupational health/CCIH sector, considering reports of dissatisfaction in the care received in process, as well as complaints about the bureaucracy to fill out the forms that relate to the notification [20] [22] [23].

It is noteworthy that the accident at work must be reported, including the issuance of CAT contributing to the planning of actions aimed at the prevention of diseases and/or injuries and for the promotion of workers' health [24]. Thus, the impact of training on indices of notification is of utmost importance and should be analyzed and evaluated with caution, with due consideration to the type of knowledge that they have provided in training the professionals.

In the study, the occupation distribution and Viral Hepatitis B and C had higher prevalence in the category "ignored”. However, the prevalence of both viruses indicates higher occupational transmission associated with the hospital work environment where the risk and exposure becomes greater. In a study [25] the occurrence of $\mathrm{HCV}$ among health professionals varies from $2 \%$ to $10 \%$, and is associated with the risk of infection to the time of service, invasive procedures, and the occurrence of percutaneous injuries.

It is known that the workforce of health institutions, especially hospitals, consists largely of technicians/ nursing assistants, since these professionals provide uninterrupted service for 24 hours and are responsible for about $60 \%$ of the actions related to customer service [26]. Nursing is different from other categories of health professionals, as they spend the most time with patients, thus exposing themselves to many risks, and may ac- 
quire occupational diseases and injuries as a result of work [27].

In characterizing exposure and outcome for Hepatitis B and C, exposure to biological material most often occurred for more than six months. This means that the worker suffered the accident but not notified immediately, delaying immediate access to post exposure prophylaxis. The search for the services to begin the research and intervention can occur at work post-accident involving exposure to biological material; by notification of the accident, or days, months or even years after the occurrence of the event, and in the case of the carrier manifesting symptoms of infection. However, as Viral Hepatitis' are silent diseases, the diagnosis can become very difficult when individuals have no symptoms. These symptoms can take up to 20 - 30 years to appear, or they might not necessarily be present at all [28] [29].

The research in this area is a major challenge for the health of the worker. They need to implement surveillance strategies in occupational health which aim to accompany injured workers throughout the period of infection and its window period. From that period, the infection may not show symptoms but can be transmitted and there are high chances that the infected/injured quit the treatment process and then access to intervention measures to control their environment become increasingly distant.

With regards to vaccination status for Hepatitis B, of the 45 workers participating in the research, the highest frequency was the "unknown" category. Health institutions should pay more attention to prevent this, as of the 03 nursing assistants, 02 were not vaccinated against Hepatitis B, and of 11 nursing technicians, 05 also ignored vaccination. Even with the Ministry of Health providing free of charge vaccination for Hepatitis B, which has efficiency around 90\% - 95\%, the vaccination status of workers was predominantly in the "unknown" and "unvaccinated" categories, demonstrating that prevention for Hepatitis B in the general population is still inadequate and needs further attention.

Corroborating data from this survey, studies on accidents with biological material pointed out some aspects such as high rates of workers not vaccinated against Hepatitis B; ignored vaccination status, absence of complete vaccination in three schemes at the time of the accident, and ignorance of their vaccination status [20] [24] [30].

These results highlight the need for constant vaccination campaigns and guidance on health services. It is understood that healthcare professionals should be followed and monitored by their work institutions, because the Ministry of Health emphasizes the need to perform evaluation of seroconversion to anti-HBs in risk groups, those that are immunocompromised, and for health professionals as immunization is not always effective even with the full vaccination status [31].

It is extremely important to emphasize the regulatory role of health institutions in the awareness and control in the conditions of immunization and protection of employees. When a worker ignores the condition of vaccination status, or presents themselves as not being vaccinated, or even with an incomplete vaccination, this situation introduces serious concerns about the quality of healthcare assistance provided and the care for their own health. Therefore it is the institutions' responsibility to introduce stricter criteria and monitor the immunization of their employees, as well as require everyone to do so for Hepatitis B immune conversion. This is true even in the condition of having complete vaccination, since it is known that this is the most effective method for confirmation of being $100 \%$ immunized. However, even if they are immunized, the use of protective equipment must be required and the readjustment of the technique whenever required.

Regarding the location of the workplace accidents, the hospital had the highest occupational exposures to biological fluids.

Other studies corroborate this research and point to the hospital environment as the place in which more exposure to biological fluids and contamination by Hepatitis B and C occur [32] [33]. This can be explained by the type of activities and developed procedures that are inherent to the care, such as administering medications and materials handling of sharp piercing objects, and the pace of work imposed [8]. Furthermore, the insufficient number of employees, overhead, stressful working hours, the continuity of care expressed by shifts and night shifts, physical and emotional exhaustion, lack of professional training, and local culture are very important factors to consider [24] [31].

With regards to the causative agents of sharp materials which were involved in most of the accidents Studies corroborate our results and indicate a sharp needle as the piercing equipment responsible for most of the accidents with exposure to biological material [19] [21] [32] [34]. The fact that the needle has been the agent involved in most accidents can be related to the more frequent professional category in the study; technicians and nursing assistants. Workers' exposure to biohazards of nursing occurs more frequently due to the large number of work activities that expose these professionals to contact with biological material, such as vehicles that can 
trigger diseases such as Acquired Immunodeficiency Syndrome and Hepatitis [35]. Whereas the nursing staff is in direct contact with the patient performing activities such as administration of intravenous medications and constant manipulation of needles and scalpels, and so these conditions expose workers to the risk of accidents at work [20].

Several studies have found that among the circumstances in which venipuncture accidents occurred, the improper disposal of cut and puncture wounds material and handling of surgical specimens was involved. This goes beyond the antivenom and the habit of recapping used needles [32] [35] [36].

The Norm 32 (NR 32), which deals exclusively with Safety and Health at Work in Health Services, highlights the importance of using PPE before performing procedures with risk of exposure to blood or body fluids, and emphasizes the use of clothing such as protective aprons. They should be compulsorily used for performing all work activities suitable for this purpose, and should be the position of the employing institution [30]. Institutions should guide and take charge in this attitude of protection of workers and take co-responsibility with their protection and assistance provided, as well as providing better working conditions. The standard precautions recommended are that needles should not be recapped, bent or broken, and one should use appropriate and adequate means for the disposal of sharp materials in proper and transportable containers [37].

Importantly, all workers exposed to biological risk should review their nursing techniques, be attentive and focused during the execution of the practice, and adopt safe behavior for the prevention of accidents at work.

The most frequent organic material involved was blood and regarding exposure of the accident, were affected with percutaneous injuries. Corroborating this study, [21] [24] [38] point out that the biological material most commonly involved in accidents was blood. Among the various types of accidents, sharp piercings are not only more frequent, but also more serious, as they enabled the development of lethal diseases for workers such as Hepatitis B [7] [20] [21] [30] [38].

The risk of contamination by blood borne pathogens among health workers and nurses after occupational exposure, and the consequences of accidents at work have been described in the literature as an important issue that needs to be urgently minimized due to the serious damage they cause workers and health services, either by suffering caused or by generated costs [23].

\section{Conclusions}

This study allowed us to learn the profile of injured workers from biological material and contaminated with Hepatitis B and C, as well as the peculiar characteristics of the occurrence of such accidents in Belo Horizonte, according to data from Information Resulting System-SINAN/PBH.

As the study's limitations, the large amount of missing data and typos in the records databases deserve to be better evaluated and there is a need to conduct systematic analysis of the completeness and consistency of the fields from reporting/investigation since conduct in-depth statistical analysis is impossible.

Our data confirm that there is a great need for reorientation of adequate safety procedures during activities undertaken by workers who work in health services, from full immunization against Hepatitis B, practice of the techniques applied in care, the use of PPE in order to reduce the accidents involving biological material and contamination by Viral Hepatitis B, C and HIV. On the other hand, institutions should be co-responsible for these conditions that the health workers are exposed to, providing guidance regarding the reporting of accidents as well as investing in processes that become less bureaucratic for reporting.

Moreover, it is of utmost importance to strengthen investments in educational programs for guidance related to the theme in hospitals, in order to establish measures that focus on prevention of this type of occurrence. However, the development of educational materials to be distributed in health units is necessary in Belo Horizonte and its metropolitan region, with instructions on measures to prevent accidents with biological fluids, complete with directions on how to proceed in cases of occupational exposure to biological material in the work environment.

Added to this absenteeism considered, a major and frequent problem experienced currently by health services, related to the illness of their professional and occupational accidents, which once occurred can cause financial losses for the organizations to government as well as loss of mental, moral and financial assistance to workers affected by workplace accidents. This situation is worrying and must be analyzed, evaluated in the working world. Soon there are more reasons that should be analyzed and evaluated in the world of work, and occupational health. 


\section{References}

[1] Brandão, P.S.J.R. (2000) Biossegurança e AIDS: As dimensões psicossociais do acidente com material biológico no trabalho em hospital. Ph.D. Dissertação, Rio de Janeiro-RJ, Escola Nacional de Saúde Pública, Fundação Oswaldo Cruz, 138.

[2] Mendes, R. (2003) Introdução ao estudo dos mecanismos de patogênese do trabalho. In: Mendes, R., Org., Patologia do Trabalho-Atualizada e Ampliada, Atheneu, São Paulo, 93-186.

[3] Campos, R.H., Mbayed, V.A., Leone, Y. and Pineiro, F.G. (2005) Molecular Epidemiology of Hepatitis B Virus in Latin America. Journal of Clinical Virology, 34, 8-13. http://dx.doi.org/10.1016/S1386-6532(05)80028-9

[4] Russi, J.C., Serra, M., Vinoles, J., Perez, M.T., Ruchansky, D., Alonso, G., et al. (2003) Sexual Transmission of Hepatitis B Virus, Hepatitis C Virus, and Human Immunodeficiency Virus Type 1 Infections among Male Transvestite Comercial Sex Workers in Montevideo, Uruguay. The American Journal of Tropical Medicine and Hygiene, 68, 716720.

[5] Afdhal, N.H. (2004) The Natural History of Hepatitis C. Seminars in Liver Disease, 24, 3-8. http://dx.doi.org/10.1055/s-2004-832922

[6] Di Bisceglie, A.M. (2000) Natural History of Hepatitis C: Its Impact on Clinical Management. Hepatology, 31, 10141018. http://dx.doi.org/10.1053/he.2000.5762

[7] Institui a Rede Nacional de Atenção à Saúde do Trabalhador (RENT) (2002) Portaria GM/MS no. 1.679, de 19 de setembro de 2002. Ministério da Saúde, Diário Oficial da República Federativa do Brasil, Brasília.

[8] Brasil Ministério da Saúde, Secretaria de Atenção à Saúde (2006) Exposição a materiais biológicos. Ministério da Saúde, Secretaria de Atenção à Saúde, Departamento de Ações Programáticas Estratégicas, Brasília.

[9] Centers for Disease Control and Prevention (CDC) (1999) Exposure to Blood What Health-Care Need to Know. Department of Health \& Human Service, Atlanta. http://www.cdc.gov/incidocid/hip/BLOOD/exp_to_Blood.pdf

[10] Centers for Disease Control and Prevention (CDC) (2001) Guideline for the Management of Occupational Exposure to $\mathrm{HBV}, \mathrm{HCV}$, and HIV and Recommendations for Postexposure Prophylaxis. http://www.cdc.gov/mmwr/preview/mmwrhtml/rr5011a1.htm

[11] Mello, C.E.B., Pires, M.M.A. and Gripp, K. (2008) A co-infecção pelos vírus da hepatite b (HBV) e da imunodeficiência humana (HIV)—Aspectos clínicos e terapêuticos. Prática Hospitalar, 56, 97-106.

[12] Rantala, M. and Van De Laar, J.W. (2008) Surveillance and Epidemiology of Hepatitis B and C in Europe-A Review. Eurosurveillance, 13, 1-8.

[13] Pruss-Ustun, A., Rapiti, E. and Hutin, Y. (2005) Etimation of the Global Burden of Disease Attributable to Contaminated Sharps Injuries among Health-Care Works. American Journal of Industrial Medicine, 48, 482-490. http://dx.doi.org/10.1002/ajim.20230

[14] Brasil. Ministério da Saúde. Portaria no. 777, de 28 de abril de 2004 (2004) Dispõe sobre os procedimentos técnicos para a notificação compulsória de agravos à saúde do trabalhador em rede de serviços sentinela específica, no Sistema Único de Saúde—SUS. Diário Oficial da União, Brasília. http://www.anamt.org.br/downloads/portaria_777.pdf

[15] Brasil Ministério da Saúde (2009) Protocolo Clínico e Diretrizes Terapêuticas para o Tratamento da Hepatite Viral Crônica B e Coinfeç̧ões. Secretaria de Vigilância em Saúde. Departamento de DST, AIDS e Hepatites Virais. Programa Nacional para a Prevenção e o Controle das Hepatites Virais, Brasília.

[16] Secretaria Estadual de Saúde de Minas Gerais (SES)/MG no. 1481 de 16 de maio de (2008) Acrescenta agravos estaduais a Lista Nacional de Doenças de Notificação Compulsória. Secretaria Estadual de Saúde de Minas Gerais. Disponível em: http://www.saude.mg.gov.br

[17] Burattini, M.N., Camargo, L.M.A., Corbett, C.E.P., Duarte, L.S., Khouri, M.E., Ribeiro, R.B., Santos, V.A., Burattini, M.N. and Silva, L.F.F. (2005) Seroprevalence of Hepatitis B Virus and Hepatitis C Virus in Monte Negro in the Brazilian Western Amazon Region. Clinics, 60.

[18] Brevidelli, M. and Cianrullo, T. (2006) Compliance with Standard-Precautions among Medical and Nursing Staff at a University Hospital. Online Brazillian Journal of Nursing, 5, Published Online. http://www.uff.br/objnursing/index.php/nursing/article/view/291/57

[19] Oliveira, A.C. and Gonçalves, J.A. (2010) Acidentes ocupacional por material prefurocortante entre profissionais de saúde de um centro cirúrgico. Revista da Escola de Enfermagem da USP, 44, 482-487. http://www.ee.usp.br/reeusp http://dx.doi.org/10.1590/S0080-62342010000200034

[20] Guilarde, A.O., Oliveira, A.M., Tassara, M., Oliveira, B. and Andrade, S.S. (2010) Acidentes com material biológico entre profissionais de hospital universitário em Goiânia. Revista de Patologia Tropical, 39, 131-136. http://www.revistas.ufg.br

[21] Valim, M.D. and Marziale, M.H.P. (2011) Avaliação da exposição ocupacional a material biológico em serviços de 
saúde. Revista Texto \& Contexto Enfermagem, Florianópolis, 20, 138-146.

[22] Smith, D.R., Mihashi, M., Adachi, Y., Shouyama, Y., Mouri, F., Ishibashi, N. and Ishitake, T. (2009) Organizational Climate and Its Relationship with Needlestick and Sharps Injuries among Japanese Nurses. AJIC: American Journal of Infection Control, 37, 545-550. http://dx.doi.org/10.1016/j.ajic.2008.11.004

[23] Marziale, M.H.P. and Rodrigues, C.M. (2002) A produção científica sobre os acidentes de trabalho com material pérfurocortante entre trabalhadores de enfermagem. Revista Latino-Americana de Enfermagem, 10, 571-577. http://dx.doi.org/10.1590/S0104-11692002000400015

[24] Silva, F.J.C.P. (2008) Ambiente hospitalar: Acidentes ocupacionais e a contaminação por hepatite B. Ph.D. Dissertação, Universidade Tiradentes, Aracajú.

[25] Proietti, L., Malaponte, G., Libra, M., Navolanic, P.M., Bevelacqua, Y., Travali, S., et al. (2005) Analysis of Hepatitis C Virus Infection among Health-Care Workers: An Observational Study. Minerva Gastroenterol Dietol, 51, $255-259$.

[26] Bulhões, I. (1998) Riscos do trabalho de enfermagem. 2nd Edition, Correio Carioca, Rio de Janeiro.

[27] Sêcco, I.A.O. and Robazzi, M.L.C.C. (2007) Accidentes de trabajo en el equipo de enfermeria de un hospital de enseñanza de Paraná—Brasil. Ciencia y Enfermería, 13, 65-78. http://www.scielo.cl/pdf/cienf/v13n2/art08.pdf.

[28] Prefeitura Municipal de Saúde de Belo Horizonte (PBH) (2012) Protocolo de abordagem do paciente com hepatite viral na Atenção Básica Secretaria Municipal de Saúde de Belo Horizonte. http://www.pbh.gov.br/smsa/biblioteca/protocolos/hepatite.pdf.

[29] Brasil. Ministério do Trabalho e Emprego. Portaria n. 485 de 11 de novembro de (2005) Dispõe sobre a Norma Regulamentadora NR-32 relativa à segurança e saúde no trabalho em serviços de saúde. Diário Oficial de União, Brasília, DF.

[30] Spagnuolo, R.S., Baldo, R.C.S. and Guerrini, I.A. (2008) Análise epidemiológica dos acidentes com material biológico registrados no Centro de Referência em Saúde do Trabalhador-Londrina-PR. Revista Brasileira de Epidemiologia, 11, 315-323. http://dx.doi.org/10.1590/S1415-790X2008000200013

[31] Pinheiro, J. and Zeitoune, R.C.G. (2008) Hepatite B: Conhecimento e medidas de biossegurança e a saúde do trabalhador de enfermagem. Escola Anna Nery (Rio de Janeiro), 12, 258-261. http://dx.doi.org/10.1590/S1414-81452008000200009

[32] Sarquis, L.M.M. (2007) O monitoramento do trabalhador de saúde, após exposição a fluidos biológicos. Ph.D.(Tese), Escola de Enfermagem da Universidade de São Paulo, São Paulo.

[33] Silva, M.K.D. and Zeitoune, R.C.G. (2009) Riscos ocupacionais em um setor de hemodiálise na perspectiva dos trabalhadores da equipe de enfermagem. Escola Anna Nery (Rio de Janeiro), 13, 279-286. http://dx.doi.org/10.1590/S1414-81452009000200007

[34] Gomes, A.C., Agy, L.L., Malaguti, S.E., Canini, S.R.M.S., Cruz, E. and Gir, E. (2009) Acidentes ocupacionais com material biológico e equipe de enfermagem de um hospital-escola. Revista Brasileira de Enfermagem, 17, $220-223$.

[35] Marziale, M.H.P., Nishimura, K.Y.N. and Ferreira, M.M. (2004) Riscos de contaminação ocasionados por acidentes de trabalho com material pérfuro-cortante entre trabalhadores de enfermagem. Revista Latino-Americana de Enfermagem (Ribeirão Preto), 12, 36-42. http://dx.doi.org/10.1590/S0104-11692004000100006

[36] Nagao, M., Linuma, Y., Igawa, Matsumura, Y., Shirano, M., Matsushima, A., Saito, T., Takakura, S. and Ichiyama, S. (2009) Accidental Exposures to Blood and Body Fluid in the Operation Room and the Issue of Underreporting. AJIC: American Journal of Infection Control, 37, 541-544. http://dx.doi.org/10.1016/j.ajic.2009.01.009

[37] Center for Disease Control and Prevention (CDC) (2005) Public Health Service Guidelines for the Management of Occupational Exposures to HIV and Recommendations for Postexposure Prophylaxis. MMWR, 1-17.

[38] Lima, L.M., Oliveira, C.C. and de Rodrigues, K.M.R. (2011) Exposição ocupacional por material biológico no Hospital Santa Casa de Pelotas—2004 a 2008. Escola Anna Nery, 15, 96-102.

http://dx.doi.org/10.1590/S1414-81452011000100014 